\title{
Māori Election Petitions of the 1870s: Microcosms of Dynamic Māori and Pākehā Political Forces
}

\author{
PAERAU WARBRICK
}

\begin{abstract}
Māori election petitions to the 1876 Eastern Māori and the 1879 Northern Māori elections were high-stakes political manoeuvres. The outcomes of such challenges were significant in the weighting of political power in Wellington. This was a time in New Zealand politics well before the formation of political parties. Political alignments were defined by a mixture of individual charismatic men with a smattering of provincial sympathies and individual and group economic interests. Larger-than-life Māori and Pākehā political characters were involved in the election petitions, providing a window not only into the complex Māori political relationships involved, but also into the stormy Pākehā political world of the 1870s. And this is the great lesson about election petitions. They involve raw politics, with all the political theatre and power play, which have as much significance in today's politics as they did in the past. Election petitions are much more than legal challenges to electoral races. There are personalities involved, and ideological stances between the contesting individuals and groups that back those individuals. Māori had to navigate both the Pākehā realm of central and provincial politics as well as the realm of Māori kin-group politics at the whānau, hapū and iwi levels of Māoridom. The political complexities of these 1870s Māori election petitions were but a microcosm of dynamic Māori and Pākehā political forces in New Zealand society at the time.
\end{abstract}

At Waitetuna, not far from modern day Raglan in the Waikato area, the Māori meeting house was chosen as one of the many polling booths for the Western Māori electorate in the 1908 general election. ${ }^{1}$ At 10.30 a.m. on the election day, the deputy returning officer telegrammed W. N. Grace, the returning officer for the whole of the Western Māori electorate, that the place was deserted. The reply from Grace was that he must stay there until 4 p.m. As a result of there being no one about, the deputy then took votes from any Māori he could find around Waitetuna. Meanwhile, at the Kihikihi polling booth, some $60 \mathrm{kms}$ southeast of Waitetuna where Grace was presiding over the election, there was no secret ballot conducted (there was no secret ballot in the Māori seats until 1937, with the Electoral Amendment Act). ${ }^{2}$ Grace offered the several Māori various voting papers and they were immediately handed back saying "I want to vote for So-and-So." ${ }^{3}$ These were just two of the various grievances that Pēpene Eketone claimed in his election petition to the Supreme Court in an attempt to stop Hēnare Kaihau from being elected as MP for Western Māori. ${ }^{4}$ This election petition, like another petition made to the courts against Kaihau some years prior, was not successful. Kaihau had successfully defended his right to the Western Māori seat in the 1896 election when Ropata Te Ao, ${ }^{5}$ the losing incumbent MP at the time, challenged Kaihau's election with allegations of bribery. ${ }^{6}$

Petitions to change an election result have always been difficult to win because of the political stakes involved. In New Zealand's recent political history, the Hunua petition before the Supreme Court (as today's High Court was known then) in the late 1970s resulted in the ousting of the Labour Party member, Malcolm Douglas, from Parliament. Instead, the National Party member at the time, Winston Peters, ${ }^{7}$ was deemed the winner of the seat. ${ }^{8}$ The result added to the already heightened animosity between the two major political parties, especially with the dominant political protoganist of the time Prime Minister Robert Muldoon. ${ }^{9}$ Prior to the

Journal of New Zealand Studies NS32 (2021), 40-59 - https://doi.org/10.26686/jnzs.iNS32.6862 
Elections Petitions Act 1880, any election disputes related to the European and Māori seats were considered by a special committee of the House of Representatives. ${ }^{10}$ The courts were not involved. The New Zealand Constitution Act 1852, which set up New Zealand's government structures, ${ }^{11}$ also stipulated the mechanism by which to challenge elections. Section 45 left it up to the House of Representatives to determine the validity of its own elections. ${ }^{12}$ In the mid 1860s, four special Māori electoral districts were created under the Māori Representation Act 1867, known as Northern Māori, Western Māori, Eastern Māori and Southern Māori. ${ }^{13}$ Māori males over the age of 21 years were given universal suffrage for the four special Māori electoral districts. ${ }^{14}$ Māori males who met the property qualifications could still vote in the other electoral districts, although Māori who tried to register to vote before 1868 were subjected to challenges. ${ }^{15}$ Any challenges to the MP's election would still have to be decided by the House of Representatives itself, in line with the New Zealand Constitution Act 1852.

Over the years, there have been a number of challenges to results for the Māori seats. None have been successful, though Hirini Taiwhanga's 1887 challenge to Wi Kātene's election by just three votes for the Northern Māori seat came extremely close. And more likely than not, Kātene would have been removed by the Supreme Court but for the dissolution of Parliament during the court hearing and a general election being called which effectively halted the case. ${ }^{16}$ This was an example of not only clashing Māori personalities, but also clashing Māori groups (whether they were organised along fraternal or kin-group lines) which tested the loyalities of not only iwi but also whānau and hapū as well. Most of the political candidates who stood for the Māori seats were well known in their districts and highly astute Māori men within their communities and broader regional areas. This was the case at least up to the 1930s: Māori candidates were aligned with rangatira and their whānau until the conditions of the Great Depression democratised the quality of the candidates that stood for elections. The use of the election petition by any candidate from the nineteenth century or early twentieth century indicated a certain amount of mana not only for them but for their supporters as well. The use of election petitions can be described as not only placating the bruised egos of unsuccessful candidates, but also showing a certain tenacity about a candidate's efforts in wanting to win an election.

The high legal and political drama involved in such challenges, and the political astuteness of some Māori candidates to use the political system to upset the initial voter outcomes of the contests, Are worthy of close analysis. However, the subject of election petitions and electoral challenges across all Māori seats is too broad for this article. There have been many Māori electoral challenges in the seats, through the late nineteenth century and into the twentieth century. A number of them are mentioned later in this article. To cover them all would be beyond the scope of this article, as each involved differing social circumstances as well as colourful political characters, such as the election petitions against Henare Kaihau (mentioned previously) and Wi Pere and James Carroll in the 1880s. ${ }^{17}$ Instead, I will concentrate on two examples: the 1876 Eastern Māori election petition; and the 1879 Northern Māori election petition. These two were extremely fascinating because they had to be determined by a committee of the House of Representatives instead of two independent judges of the Supreme Court, as required after $1880 .{ }^{18}$ Additionally, political interference by individual MPs themselves in the processes of the election petitions, when determined in the House, added an extra layer of intrigue to petitions before 1880. It is also interesting how Māori politicians used constitutional levers to continue the election fights before the House of Representatives. Election petitions were high-stakes political manoeuvres for Māori, but they had direct political 
ramifications and consequences, not only for the candidates but also for those who backed the candidates in question, whether they were Māori or Pākehā.

The 1876 Eastern Māori election petition as well as the 1879 Northern Māori election petition happened at a time of extremely unstable government in New Zealand. The 1860s land wars and land confiscations in Waikato, Bay of Plenty and Taranaki were still fresh in the minds of Māori and settlers alike. The rise of the repudiation movement in the Wairarapa, the unwillingness to create reserves in the South Island, and the ongoing Native Land Court disputes continued to dominate Māori-government relations throughout the remaining nineteenth century. ${ }^{19}$ The abolition of the provincial government system in New Zealand in 1876 also concentrated political power into central government. ${ }^{20}$ The 1870 s pre-dated the formal establishment of political parties in New Zealand, ${ }^{21}$ and therefore regional, sectional and personality politics loomed large in Pākehā politics that manifested themselves in constantly shifting political allegiances, even on a monthly basis. And at times, the politicians in the 1870 s barely managed to form workable governments. ${ }^{22}$ National political alignments prior to 1890 , therefore, were defined by a mixture of individual charismatic men with a smattering of provincial sympathies and individual and group economic interests. And so election petitions could have implications for the formation or the stability of various governments that relied on a House filled with political independents. And this added to the political complexities of the time. The outcome of the 1870s Māori electoral petitions were therefore significant in the weighting of political power in Wellington. There were larger-thanlife Māori and Pākehā political characters involved, and therefore an examination of these two electoral challenges not only gives a window into the complex political relationships involving the Māori candidates and their communities, but also the stormy national government in New Zealand of the 1870s. Therefore, this article will not only enrichen Māori political history but also New Zealand political history as well.

\section{The First Māori MPs}

The 1868 elections in the Māori electorates were somewhat novel for Māori. They had not previously had Māori candidates who sat in the House of Representatives, let alone widespread voting within their own communities for such candidates. The Northern Māori and Western Māori elections each resulted in just one candidate being elected unopposed. ${ }^{23}$ The Eastern Māori seat involved a nomination contest where one of the candidates did not know the election procedure properly and therefore ceded the election to the other candidate without an electorate-wide election. ${ }^{24}$ And the Southern Māori seat, although contested, resulted in a miniscule turnout of voters, perhaps as a result of the novelty of the election procedures. John Patterson won the seat with just 42 votes, compared to Thomas Green getting 33 votes and Wi Nahera securing only 5 votes. ${ }^{25}$ Native Land Court sittings in Canterbury as well as muttonbird harvesting in Southland around the time of voting affected the turnout. And there was not a register of the number of eligible voters anyway. But, eventually, four candidates were declared successful in becoming the first Māori MPs. However, there was a problem with the newly elected member for Western Māori, Mete Kīngi Paetahi. He was ineligible to stand as a candidate under the Disqualification Act 1858 because he was a government employee. Potentially, Mete Kingi could have been challenged as an MP through an election petition. In order to get around this potential legal problem, Native Affairs Minister Donald McLean (Napier) had a special piece of legislation passed to validate the first Western Māori election known as the Mete Kīngi Paetahi Election Act 1868. Mete Kīngi had been closely associated with Donald McLean for many years and so McLean was keen to promote a natural ally into 
the House who would vote with the government bloc of MPs, comprising the factions of William Fox and Julius Vogel. ${ }^{26}$

By the 1871 Māori elections, Māori election participation rates had improved, with three of the four seats being decided in contested elections. Māori started to go to the polling booths in higher nunbers (and this was to increase with subsequent elections). In respect of the Eastern Māori seat, Karaitiana Takamoana was elected unopposed in the 1871 contest, as Tāreha Te Moananui, the inaugural Eastern Māori MP, did not seek re-election. ${ }^{27}$ In the Western Māori electorate, the candidates - who were important leaders amongst the several iwi within that large electorate-were involved in a spirited election campaign. The result was that Wì Parata managed to defeat not only the well-known Māori leader Major Kemp, but he also managed to unseat the incumbent MP Mete Kīngi Paetahi. ${ }^{28}$ In the Southern Māori seat, an astute Ngāi Tahu rangatira, Hōri Kerei Taiaroa, won the seat with a healthy majority, marking the beginning of his dominance and popularity in the electorate. ${ }^{29}$ Hōri Kerei Taiaroa was elected unopposed on three different occasions in the 1876 general election, ${ }^{30}$ the by-election, ${ }^{31}$ and the general election of $1881 .{ }^{32}$ Only on one occasion in the Southern Māori seat was there a question about the propriety of the election result. This was in the 1884 general election, in which Hōri Kerei Taiaroa was elected yet again. ${ }^{33}$ Hōne Paratene also known as John Patterson, who was the inaugural MP for Southern Māori in 1868, sent a formal petition to the House of Representatives. However, Paratene's petition was dismissed at that time because the House no longer had the power to trial election petitions. The Chairman of the Native Affairs Committee, James Bradshaw (Dunedin Central), noted the following: "Petitioner alleges that at the late election for the Southern Māori District several things were done which were illegal, in consequence of which he asks that a fresh election may take place. I am directed to report as follows: That this is a question which can only be settled in a law Court." 34 This demonstrates that Māori were using all sorts of procedures, whether successful or not, to challenge election results. It did not matter whether the House had legal powers to investigate challenges or not, as Māori were still going to complain in whatever forum they could get an audience. For example, in the 1871 Northern Māori election, it is unknown what the final vote tallies entailed; however, Wi Kātene won the seat against four other candidates. ${ }^{35}$ The candidate in second place was Hirini Taiwhanga, who complained bitterly to Donald McLean, who was the native minister at the time, about the election, on the grounds that Wiremu Kātene "subverted one voter and that some of the notices were distributed too close to election, so that 235 Taiwhanga supporters did not vote." 36 Nothing came of that Taiwhanga protest, but it was showed that if Māori were unhappy with a result, they were going to make their grievances known to those in authority.

\section{5-1876 Elections and the Eastern Māori Election Contest 1876}

A general election was called at the end of 1875, as a result of a weak government administration led by the figurehead premier, Daniel Pollen. He was a member of the Upper House, the Legislative Council, and was associated with the Fox, Vogel and McLean factions in Parliament. The general election for all seats took place between 20 December 1875 and 29 January 1876, with different electoral districts having their elections on different days over the course of a month. A new government was formed with Julius Vogel being premier for much of 1876, but like the Pollen administration, the Vogel Government was unstable. ${ }^{37}$

Karaitiana Takamoana (Eastern Māori) had a track record of voting with the Stafford factions in Parliament, and when there was a discrepancy in the Eastern Māori votes in 1876, it was ripe for an electoral challenge by the Fox, Vogel and McLean bloc of MPs. Indeed, Karaitiana

Journal of New Zealand Studies NS32 (2021), 40-59 - https://doi.org/10.26686/jnzs.iNS32.6862 
Takamoana had increasingly become associated with the repudiation movement amongst Māori in the Eastern provinces of the North Island. That movement supported "repudiating" all the Māori land sales to the Crown and Donald McLean had personally benefitted from those land sales, as he subsequently acquired vast tracks of Crown land. ${ }^{38}$ Therefore, the Eastern Māori election was subjected to a formal challenge in the House of Representatives, and the challenge had Donald McLean's finger marks all over it.

The instructions for the Māori electoral districts were published in the Māori newspaper Waka Māori on 14 December 1875. Samuel Locke, the resident magistrate at Napier, was the returning officer for Eastern Māori where he was required to hold the nomination meeting for candidates on 4 January 1876 in Napier, and then at various polling places if needed on 15 January $1876 .{ }^{39}$ Locke was a close associate of Donald McLean, who was responsible for his appointment as resident magistrate. ${ }^{40}$ At the nomination meeting in Napier, the names of four members were put forward. Karaitiana Takamoana was nominated by Harawira and seconded by Hēnare Matua; ${ }^{41}$ Hōtene Porourangi was nominated by Hutana Taru and seconded by Tāmihana Kakenga; Mita Hikairo ${ }^{42}$ was proposed by Tāmati Hapinau and seconded by Patoromu Ngamaunga; and Te Keepa Rangipūawhea was nominated by Kawana Mokonuiārangi and seconded by Renāta Ngahana. ${ }^{43}$ Locke theren had just over ten days to organise an election through the whole electoral district.

The election not only tested the abilities of the four male candidates involved; it also tested the complex political alignments and loyalties of the various tribal groups throughout the Eastern Māori electoral district that comprised vast geographical areas of the Wairarapa, East Coast, central North Island and the wider Bay of Plenty district. Karaitiana Takamoana's base was principally Ngāti Kahunungu in the Wairarapa. As noted earlier, he was aligned with the Stafford-led opposition factions in Parliament, which included Sir George Grey, who was first an MP for Auckland West in the 1871-1875 term, but then an MP for Thames in the 1876 term. It was noted in the papers in January 1876 that Karaitiana voted with the opposition. ${ }^{44} \mathrm{Wi}$ Hikairo and Te Keepa Rangipūawhea respectively were aligned with various tribal groups of the Te Arawa Confederation in the western Bay of Plenty. Te Keepa was a dominant leader of Tūhourangi. ${ }^{45}$ Mita Hikairo was of Ngāti Rangiwewehi, and he was also a native assessor in the Native Land Court in the 1860 s and 1870 s. $^{46}$

Hōtene Porourangi was an older leading rangatira of Ngāti Porou. ${ }^{47}$ Hōtene, along with his relatives Rāpata Wahawaha and Mōkena Kōhere, repelled Pai Marire anti-government forces in the 1860s. These men were particularly close to Donald McLean. McLean had supplied them with ammunition and supplies at critical times, enabling them and their kin to survive the battles with Pai Marire. ${ }^{48}$ Hōtene had even become close friends with Donald McLean, and he and Rāpata Wahawaha even accompanied McLean to the Australian colonies in $1874 .{ }^{49}$ Essentially, Hōtene was McLean's candidate.

On 15 January 1876, the results of the voting at the several polling places through the Eastern Māori electoral district were as shown in Table 1. 
Table 1. Statement of Votes polled for the Eastern Māori Electoral District in the General Election of $1876^{50}$

\begin{tabular}{|c|c|c|c|c|}
\hline & $\begin{array}{l}\text { Karaitiana } \\
\text { Takamoana }\end{array}$ & Mita Hikairo & $\begin{array}{l}\text { Te Keepa } \\
\text { Rangipūawhe }\end{array}$ & $\begin{array}{l}\text { Hōtene } \\
\text { Porourangi }\end{array}$ \\
\hline Greytown & 38 & 0 & 0 & 1 \\
\hline Pōrangahau & 27 & 0 & 0 & 1 \\
\hline Waipawa & 77 & 0 & 0 & 0 \\
\hline Napier & 127 & 0 & 0 & 0 \\
\hline Taupō & 11 & 0 & 37 & 0 \\
\hline Wairoa & 17 & 0 & 0 & 27 \\
\hline Māhia & 32 & 1 & 0 & 12 \\
\hline Gisborne & 17 & 0 & 0 & 48 \\
\hline Tolaga Bay & 0 & 0 & 0 & 16 \\
\hline Tokomaru & 1 & 0 & 0 & 6 \\
\hline Waiapu & 22 & $\mathbf{0}$ & $\mathbf{0}$ & 25 \\
\hline Kawakawa & No poll & No poll & No poll & No poll \\
\hline Te Kaha & 0 & 44 & 0 & 4 \\
\hline Ōpōtiki & 1 & 64 & 105 & 5 \\
\hline Whakatāne & 1 & 77 & 14 & 0 \\
\hline Matata-Tāheke & 0 & 95 & 34 & 0 \\
\hline Maketu & 0 & 52 & 59 & 0 \\
\hline $\begin{array}{l}\text { Ōhinemutu- } \\
\text { Tarawera }\end{array}$ & 30 & 43 & 124 & 0 \\
\hline Final result & 401 & 376 & 373 & 145 \\
\hline
\end{tabular}

As can be seen, Mita Hikairo and Te Keepa Rangipūawhe, both of Te Arawa managed to secure large numbers of votes in the Bay of Plenty area that covered Te Kaha, Ōpōtiki, Whakatāne (Mataatua tribal areas), and the Matata-Tāheke, Maketu, Ōhinemutu and Taupo areas (Te Arawa tribal areas). Both also secured no votes in the other areas that covered the eastern coastline of the North Island, which were the tribal areas that Karaitiana and Hōtene belonged to (except the one vote that Mita Hikairo got in Māhia). Mita and Te Keepa split the votes within their tribal groups between them, which allowed Karaitiana to become the highest polling candidate. Most importantly, though, Karaitiana received 30 votes in Mita's and Te Keepa's stronghold area of Ōhinemutu-Tarawera in the Te Arawa tribal territory, which allowed Karaiatiana to prevail over both Mita and Te Keepa. However, the electoral challenge in this instance was not from Mita and Te Keepa, but from the candidate who was in last place: Hōtene Porourangi of Ngāti Porou. It was the results from the Waiapu and Kawakawa polling booths (shown in bold in Table 1) that brought the election results into dispute.

The Kawakawa polling booth could not be opened on the election day. This was because of flooding and the inability of the deputy returning officer and resident magistrate, J. H. Campbell, and his son the other deputy returning officer, F. W. Campbell, to get to Kawakawa. Hōtene's voters, it was claimed, were therefore denied their vote because Kawakawa was a major voting area of Hōtene's tribal group of Ngāti Porou. The other issue related to the votes recorded for Waiapu. The polling booth was not opened at Waiapu but rather at Te Awanui because of the mistaken belief of J. H. Campbell that the poll was to be taken at the Te Awanui

Journal of New Zealand Studies NS32 (2021), 40-59 - https://doi.org/10.26686/jnzs.iNS32.6862 
courthouse rather than the Waiapu schoolhouse. Waiapu was another stronghold of Ngāti Porou voters, and it was therefore claimed that Hōtene was denied their votes as well.

Samuel Locke, the returning officer for Eastern Māori in Napier, when informed by J. H. Campbell about the result at Kawakawa, telegraphed the undersecretary of native affairs, Henry Halse, on 26 January 1876 for guidance. ${ }^{51}$ He wanted legal advice from the attorney general about what to do in the situation, as he could not declare a result for the election. ${ }^{52}$ However, Halse would not give him directions, as it was deemed improper on the grounds that the House of Representatives was the proper body to determine election disputes. Instead, Halse instructed Locke to seek the best legal advice he could and then return the writ of election that should have the name of the winning candidate, with or without a name attached ${ }^{53}$ Locke then sought advice from his own personal lawyer in Napier, who in turn sought advice from the Auckland and Dunedin legal professions. ${ }^{54}$ The result of the advice was that Locke did not endorse and attach the name of a winning candidate to the official writ for Eastern Māori when he returned it to the Governor. Locke instead sent in a special return to the governor that indicated the problems with the Kawakawa polling booth and he noted the aggregate number of votes at the polling booth for each candidate other than the polling place of Kawakawa. These were, as shown in Table 1, Karaitiana (401 votes); Wi Hikairo (376 votes); Te Keepa (373 votes); and Hōtene (145 votes). Therefore, there was no official declaration from Locke about who was the winner. However, Locke had been keeping Donald McLean appraised of the progress of votes from at least 20 January 1876. In a letter, he mentioned the results from the Taupō polling booth, and he noted that Hēnare Tomoana (brother to Karaitiana) had taken 100 voting papers to Tokomaru Bay. ${ }^{55}$ He further apprised Sir Donald that Te Arawa had secured over 750 votes, and that if Ngāti Porou does well then Hōtene "should get in with a large majority." 56

In late January 1876, as a result of the disputed outcomes, Major Rāpata Wahawaha and Hēnare Potae drafted their petitions protesting the conduct of the election. Locke then forwarded Major Wahawaha's petition, signed by 170 members of Ngāti Porou, to the governor, Lord Normanby, on 10 February $1876 .{ }^{57}$

Wai-o-matatini, Waiapu

31 January, 1876

... This is a petition from us, the whole of the people of the Ngatiporou tribe to you, praying that you will sanction the polling for the election of a member of the Eastern Maori Electoral District to be repeated. The reason of our petition is-

Firstly. No poll took place at the Kawakawa, owing to the absence of the Deputy Returning Officer.

Secondly. That the people were debarred from recording their votes on account of the excessive rain on the day appointed for taking the poll.

Thirdly. That the people of Waiapu were not acquainted with the system of voting. Concluded.

We subscribe our names on the appeal of the whole tribe.

Meiha Ropata Wahawaha (and 109 others)... ${ }^{58}$

From that point, there was a stalemate in the election. The returning officer would not declare the winner, and therefore the matter had to go to the House of Representatives to decide the outcome. The parliament at the time did not meet for large parts of the year, and therefore it

Journal of New Zealand Studies NS32 (2021), 40-59 - https://doi.org/10.26686/jnzs.iNS32.6862 
was not until nearly six months later, on 30 June 1876, that the House finally appointed a select committee to inquire about the election and to make their report. ${ }^{59} \mathrm{~A}$ political contest involving rivalries between various Māori individuals and tribal groups in the Bay of Plenty, the centralnortheastern, and East Coast areas of the North Island, had now gone into the Pākehā dominated House of Representatives. The Eastern Māori contest was therefore going to be decided by Pākehā individuals with their own political and regional rivalries on top of varying sympathies to Māori groups, which added further complexity to the issue.

\section{Initial Select Committee of the House}

Donald McLean dominated native affairs in the Fox, Vogel and Pollen administrations. He had been the MP for Napier since 1866, and served as minister of native affairs from 1869 to shortly before his death in January 1877. He was influential in passing the legislation that created the four Māori seats in 1867. And before his election to Parliament, McLean was also the head of the Hawkes Bay provincial government, from 1863 till 1869. McLean therefore knew all of the Māori political players involved in the election dispute. He also made sure that he was to be seated as a member of the select committee to determine the Eastern Māori election result. Despite McLean not attending the first day of the hearings on 3 July 1876, he was nonetheless present for the subsequent eight days of deliberations. At the first meetings of the committee on 3 July and 4 July 1876, various documents were filed and the Rapata and Hēnare petitions were read.

Joseph Tole, the newly elected member for Eden, who was Catholic and an extremely pugnacious lawyer associated with Sir George Grey and the opposition, was keen for Karaitiana Takamoana to take his seat until the allegations were determined. However, his motion was deferred on the 3 July and defeated on the 4 July. ${ }^{60}$ A subsequent motion was then put by McLean on 4 July and passed, which resolved that "no member was returned and a fresh election held without delay." 61 The way in which the committee actually voted is unknown. But the committee included some member who I would call McLean supporters, many from Otago and Southland - namely Horace Bastings (Waikaia), Donald Reid (Taieri) and George Lumsden (Invercargill), George Hunter (Wellington), and John William Williams (Mangonui and Bay of Islands) - who may have voted for the motion. And then there were those who were not particular supporters of McLean, such as Joseph Tole (Eden), William Montgomery (Akaroa), William Wood and former premier Edward Stafford. ${ }^{62}$ On these brief observations, there would have been enough votes for the resolution to pass.

However, the committee's resolution was not the end of the matter. When the committee's recommendation went before the whole House of Representatives later in the day, it was promptly referred back to the committee with a specific point of reference. The committee had to ascertain whether any persons had been prevented from voting and if so whether the number prevented would have altered the votes given at the polling places where the votes were taken. ${ }^{63}$ This political outcome showed the influence of the opposition forces against the Vogel Government and particularly Donald McLean. Sir George Grey (Thames), Henry Bunny (Wairarapa), James Macandrew (Dunedin), Hugh Lusk (Franklin) and Joseph Tole were extremely critical of the government wanting a new election when the matter went before the whole House of Representatives. ${ }^{64}$

\section{Continued Select Committee Hearings}

When the select committee reconvened on 6 July 1876, it began to hear evidence from the petitioners themselves about the conduct of the election. These were Rappata Wahawaha and

Journal of New Zealand Studies NS32 (2021), 40-59 - https://doi.org/10.26686/jnzs.iNS32.6862 
Hēnare Potae, as well as Mohi Tūrei, who favoured Hōtene Porourangi. Two MPs from the East Coast who were also aligned with McLean such as John Ormond (Clive) and Captain William Russell (Napier) also gave evidence in favour of Hōtene's case. Surprisingly, Hōtene himself did not give evidence before the committee. Those who gave evidence in support of Karaitiana's case included Karaitiana himself as well as his brother Hēnare Tomoana. Wiremu Wanoa, although of Ngāti Porou, also backed Karaitiana's cause. The MP John Sheehan (Rodney), who would become native minister in a future Grey administration (1877-1879), also gave evidence in support of Karaitiana. Sheehan's friendship with Karaitiana predated both of them being in Parliament: John Sheehan, as a steadfast lawyer, had represented Karaiatiana in litigation involving the repudiation of land sales. The two further witnesses before the committee included the returning officer for Eastern Māori, Samuel Locke, and also Mōkena Kōhere, who was a member of the Legislative Council. ${ }^{65}$ Mokena had genealogical ties to Ngāti Porou and he was asked about the number of voters around the various polling booths in question. The two other important witnesses were the resident magistrate, J. H. Campbell, and his son, F. W. Campbell, the already-mentioned deputy returning officers. It was their evidence before the select committee, as well as the evidence given by John Sheehan, that was instrumental in the outcome. The Campbells had not followed election procedures, and John Sheehan emphasised how many potential voters were not able to cast their votes.

The critical issue before the select committee was whether there was a sizable number of voters at Kawakawa and Waiapu (Ngāti Porou strongholds) who would have voted for Hōtene but were denied the vote. In other words, were there 261 voters in those places that would enable Hōtene to overtake Karaitiana's tally. The known facts were that the Kawakawa polling booth was not opened on the day, and that the polling booth was not opened at the Waiapu schoolhouse but instead at the Te Awanui courthouse (where Karaitiana had supporters), with the votes taken there marked as being taken at Waiapu.

The hearings started to focus on the number of people who would have voted at Waiapu and Kawakawa. And there were disputes as to exactly how many Ngāti Porou members were actually resident at those places (and who presumably would have voted for Hōtene). Mohi Tūrei, Hēnare Potae and Mōkena Kōhere opined varying numbers of voters at Kawakawa, confusing the committee. They suggested 250, 350 and 400 people at Kawakawa, respectively ${ }^{66} \mathrm{~J}$. H. Campbell then had a different number of voters, as well: he said there were between 250 and 300. Wiremu Wanoa disagreed with these numbers. Instead he indicated that there were between 75 and 78 voters, and that in any case they would have voted for Karaitiana. ${ }^{67}$ This was backed up by Hēnare Tomoana who thought 80 members at Kawakawa would have voted for Karaitiana. ${ }^{68}$ As to the numbers at Waiapu, Karaitiana said there were only 100 voters, ${ }^{69}$ whereas Rāpata Wahawaha said there could have been 700 . However, Rāpata could only produce a list of 70 names. ${ }^{70}$ John Sheehan's evidence, though, was particularly persuasive as to a the number of voters at the two disputed polling booths. Sheehan quoted a census of 1874 that stated the whole of the Ngāti Porou iwi was 841 people aged 15 years or over. By implication, the number of male voters at just the two polling places could not be in the range of 200-300. Instead, it would be more modest. John Sheehan's evidence as to the method of voting was particularly revealing, in that votes for Hōtene were suspect anyway, ${ }^{71}$ because the acceptable method of voting on election day was not followed.

The gathering of votes was conducted by J. H. Campbell and his son F. W. Campbell using the older voting practice amongst Māori. The names of the voters would be collected before the polling day by rangatira and recorded on the polling day. Sheehan termed this "the Māori

Journal of New Zealand Studies NS32 (2021), 40-59 - https://doi.org/10.26686/jnzs.iNS32.6862 
fashion" and he mentioned that Karaitiana had 303 votes in the Wairarapa disallowed because of this method. ${ }^{72}$ Hēnare Tomoana said that there was a preliminary election by Mr. Campbell where there was a list. The list was employed to legalise the election as a type of form. And this is where Hēnare objected to the practice at Te Awanui. ${ }^{73}$ Critically, this method of collecting votes was backed up by Rāpata Wahawaha.

... it was before the election that Mr. Campbell sent the books around to the different settlements, so that people can send their names to do voting for one of the candidates. ... I signed the book as well as all my hapu ... they were papers about the size of banknotes. .. . It was agreed that Hōtene's name should be written in when we got the books. ${ }^{74}$

On the evidence, the committee therefore could not find the number of votes in order for Hōtene to succeed. This was even with counting the votes for Hōtene (which were suspect anyway) in a book held by the deputy returning officer as well. The numbers just were not there. Accordingly, the final report of the select committee confirmed Karaitiana's election, as there was conflicting evidence whether the polling booth at Kawakawa would have made any difference to the final result. ${ }^{75}$

The Eastern Māori election petition of 1876 is the only example of a disputed Māori seat in which a select committee was convened and fully investigated the matter. The major reason for this has to be put down to the efforts of Donald McLean, who was the native minister for large periods of time (1869-1876), part of the ruling Vogel Government, and interested in an alternative outcome to the election. Donald McLean held a powerful sway over native affairs at the time, but when an election issue made its way into the Pākehā political arena of the House of Representatives, he found that his powers could in fact be limited. Within less than 6 months of the conclusion of the 1876 select committee hearings, Donald McLean was dead. And by October 1877, Sir George Grey and his supporters formed a new government replacing the long serving Fox, Vogel and McLean bloc in power. John Sheehan, whose evidence before the select committee was instrumental in confirming Karaitiana Takamoana into his Eastern Māori seat, became the new native affairs minister. However, the nature of the ever-shifting allegiances within the House during the 1870s meant that Grey's government was an unstable administration, like previous ones. Between August and September 1879, a fresh set of elections then took place, which Sir George Grey was confident of winning. Ebenezer Fox, writing to Sir Julius Vogel in mid September 1879, noted that though "The elections are nearly over" he could not tell the result of the elections. "What is the net result, who can tell? ... [I]t is really harder than usual to guess the composition of the House any possible party composition [sic]."76

The Māori seats were won by members who could work with a Grey and Sheehan administration, such as Ihaia Tainui, who had replaced Hōri Kerei Taiaroa in the Southern Māori seat when the later was appointed to the Legislative Council. The newly elected Major Wīremu Te Wheoro for Western Māori had been closely associated with Grey when he was governor and also premier, so it was assumed that he would support the Grey ministry. ${ }^{77} \mathrm{C}$. J. Stevens (Christchurch), writing about the vote to Sir Edward Stafford who had then retired, mentioned that "Te Wheoro was influenced by Sheehan to come into the House to vote but being in, he of course had to vote and said he must vote with the Government as things stood."78 The also newly elected Hōne Mohi Tāwhai of Northern Māori had also defeated Hōri Karaka Tāwhiti who had been associated with opposition factions in Parliament. And so the Grey Government was confident that they could rely on his vote. And Hēnare Tomoana (Eastern

Journal of New Zealand Studies NS32 (2021), 40-59 - https://doi.org/10.26686/jnzs.iNS32.6862 
Māori), the half brother of Karaitiana Takamoana, the former MP, was assumed to have been a supporter of the Grey ministry as well, given the workable relationship that John Sheehan had with Karaitiana Takamoana.

\section{The Aftermath of the 1879 General Election}

When Parliament reconvened in October 1879, a dramatic change of events ensured the fall of the Grey Government. In an opportunistic motion of no confidence on 3 October 1879, led by the newly elected Cantabrian John Hall (Selwyn), Sir George Grey lost by two votes. ${ }^{79}$ John Hall had been steadily wooing four Auckland MPs, often disparagingly referred to as "the four Auckland rats," to support his ministry. These were Reader Wood (Waitemata), William Hurst (Auckland West), William Swanson (Newton) and William Colbeck (Marsden). They had previously supported Grey and were assured that public works funds would be secured for Auckland interests. ${ }^{80}$ Ebenezer Fox, who kept Sir Julius Vogel informed of the political posturings, had mentioned that "Reader G Wood in the days that followed ... was certainly abused as no other man ever was in New Zealand." He even mentioned that what the four Auckland MPs did was "a shameful compact, a degrading bargain, and unheard villainy and so on." 81

It was, however, the vote of Hēnare Tomoana that sealed the fate of the Grey Ministry. Hēnare Tomona and Major Te Wheoro had a meeting with John Hall at the residence of a Mr. Locke on the day of the no confidence vote. Because of the language difficulties between Hall not understanding Te Reo Māori and Hēnare Tomoana not understanding English, Hēnare Tomoana had assumed that he would be given certain powers as a native minister in cabinet. He thought he was to have real power, in particular to dealing with Māori land. ${ }^{82}$ Specifically, Tomoana understood that Māori prisoners (presumably from Parihaka) were to be released, and the Waikato restored (presumably this would be in relation to granting confiscated Māori land in the Waikato back to Māori). ${ }^{83}$ After the vote of no confidence, the Hall faction, now in government, began to dispute Hēnare Tomoana's recollection of certain assurances given by John Hall, but the damage was already done to Grey's administration. ${ }^{84}$ However, the newly formed Hall administration's majority in the House was not assured. And it is in this political context that one has to understand the attempt at an election petition against the newly elected Northern Māori MP, Hōne Mohi Tāwhai.

\section{Northern Māori Election 1879}

Immediately, Grey's supporters began to plan putting a vote of no confidence of their own against the Hall Government. With the shock actions of the "four Auckland rats," Grey's supporters were in no mood to entertain any electoral petition against one of their own, a petition that could deliver John Hall a further Māori MP to buttress his wafer-thin majority. When Hirini Taiwhanga drafted a petition disputing the outcome of the Northern Māori Election of 1879, his efforts were met by complete stonewalling by various MPs who did not want a bar of it. Hōne Mohi Tāwhai had unseated the incumbent MP Hōri Karaka Tāwhiti when the Māori electorates went to the polls on 8 September 1879. The votes were split between five candidates, producing the following results: Hōne Mohi Tāwhai (397); Hirini Taiwhanga (332); Timoti Puhipi (303); Heta Te Hara (233); and Hōri Karaka Tāwhiti (204). ${ }^{85}$ The newspapers initially did not know which political faction Hōne Mohi Tāwhai would support in the House. One newspaper described him as being doubtful about the position he would take in the new parliament. ${ }^{86}$ However, it was clear in the vote of no confidence on 3 October 1879 that he supported the Grey administration. As a result of this political alignment, Hirini Taiwhanga's election petition to remove Hōne Mohi Tāwhai could not get a hearing 
before a committee in the House of Representatives. Grey's supporters, led by very able lawyers Cecil de Lautour (Mount Ida) and Joseph Tole (Eden) - the latter of whom sat on the 1876 select committee for the Eastern Māori election petition, as already noted—dug in with various parliamentary stalling tactics

George Beetham (Wairarapa), who supported the newly formed Hall administration, was in receipt of Hirini Taiwhanga's petition, and he attempted to present it to the House on 10 October 1879. Taiwhanga had written a letter to the returning officer on 15 September 1876, asserting that the election of Hōne Mohi Tāwhai was altogether illegal under the Disqualification Act 1878. The legislation prohibited those who were drawing a salary from the government from standing for election, as in the 1868 case of the Māori MP for Western Māori Mete Kīngi Paetahi, under previous disqualification rules. Both Hōne Mohi Tāwhai, who polled first, and Timoti Puhipi, who polled third, were native assessors, and they did not send in their resignations to the government before the day of their nomination. Taiwhanga's petition also alluded to corruption practices, such as instances of bribery during the election, as well. ${ }^{87}$ George Beetham proposed that a committee formally be appointed to investigate the allegations in the petition. He further proposed that the quorum was five members and that they needed to report back to the House within a week of their appointment. His proposal also indicated a membership that was weighted heavily towards Hall Government sympathisers: ${ }^{88}$ himself, Alfred Brandon (Wellington Country), William Murray (Bruce) John Ormond (Clive) and William Rolleston (Avon). Only three members were to be aligned with the opposition. These were to be Sir George Grey, Cecil de Lautour (Mount Ida) ${ }^{89}$ and Thomas Hislop (Waitaki). ${ }^{90}$

Cecil de Lautour and Joseph Tole refused to have the petition presented to the House, purely along procedural grounds. Beetham could not file the petition according to the standing orders of the House. The petitioner themselves had to follow the strict filing requirements, Additionally the petition did not meet other bureaucratic filing requirements as well, under the Election Petitions Act 1858 and Election Petitions Act Amendment Act 1862. ${ }^{91}$ This general stalling tactic was backed up in the parliamentary debates by other Grey supporters. These included the former native minister John Sheehan, who now represented Thames, ${ }^{92}$ and William Montgomery (Akaroa), who was well versed in the use of election petitions, having been removed from his seat by an election petition in $1874 .{ }^{93}$

Reader Wood (Waitemata), one of the "Auckland rats" who was openly despised by the opposition at this point, spelt out exactly the political reality behind the appointment of a committee:

... in the English House of Commons, when election petitions were presented, the only thing that a party required to know was the constitution of the Committee which was to try the case of the person petitioned against. As soon as they knew the constitution of the Committee, they knew perfectly well what the result would be. Now if they applied the same principle to the constitution of this Committee, they also knew perfectly well what the result would be. There were five on one side, and three on the other. Votes at the present time were exceedingly scarce, and there was not the slightest doubt that five would preponderate over three, and out the honourable gentleman would have to go, law or no law, justice or no justice. ${ }^{94}$

Such was the sentiment believed by Grey supporters, that the select committee would be stacked. Thomas Hislop (Waitaki) proposed a wider membership than the individuals proposed

Journal of New Zealand Studies NS32 (2021), 40-59 - https://doi.org/10.26686/jnzs.iNS32.6862 
by George Beetham. Three members were supporters of Hall but could have a level of independence given the circumstances. Another "Auckland rat," William Swanson (Auckland), and Albert Pitt (Nelson) were proposed ${ }^{95}$ because of their independent streak. ${ }^{96}$ William Downie Stewart (Dunedin) was added to the list, because he was incensed at not receiving a cabinet position in the Hall administration. And added to the list was the ever-combative Grey supporter, Joseph Tole (Eden).

Ihaia Tainui, the Southern Māori MP, though aligned with the Grey supporters, spoke to the substance of Taiwhanga's claim. Tainui's observations were very illuminating in his short speech before the House, and shows the quality of the speeches given by the Mâori MPs at the time when addressing issues before Parliament. Devoid of procedural motions, he had a number of instructive points that demonstrated Māori understandings of the electoral system, much as John Sheehan had described the "Maōri fashion" of voting during the electoral petition hearings for Karaitiana Takamoana in 1876. ${ }^{97}$ Tainui thought it was unfair to have Hōne Mohi Tāwhai disqualified on the basis that he was employed by the government, as this was not explained to him by the returning officer. He interestingly said that bribery was something that was not understood by Māori as well (it being a European concept and against Māori cultural norms to reward supporters), so this was unfair on the MP as well. He advocated that these types of rules for the election should be translated into Māori so that Māori could fully understand these types of technicalities. Tainui was also instructive about Hirini Taiwhanga as well. He mentioned that he had stood for the seat three times previously without getting elected and therefore he felt aggrieved, and that this was behind the petition. ${ }^{98}$ This last point is a valuable insight to the reasons for election petitions because it touches upon the human component of hurt and grievance in these political matters that should not be overlooked in such petitions. It is the hidden side of election petitions, and is missing in the archival historical record. Māori political leaders are human beings with all the range of human emotions and frailties. Trying to conduct election campaigns as well as navigate complex relations was tiring. Being an unsuccessful candidate or supporter was always disappointing, not only for the individual but also wider kin groups as well, especially if there were older rivalries between Māori.

After various further speeches from the government and opposition members, Premier John Hall called for a proper examination of the issues. However, the petition could not be filed in the House on that day because the Speaker, Maurice O'Rorke (Onehunga), who was a Grey supporter, simply ruled that it was not a matter of urgency for the House to consider. ${ }^{99}$ And in effect, the petition got overshadowed by the political realities of the following days and weeks ahead. Sir George Grey himself was subject to an election petition at the time. A committee was convened in late October 1879 when the Christchurch election was challenged because Sir George had already won one of the Thames seats and therefore he was ineligible to hold the Christchurch seat. Edward Richardson was then declared the winner. ${ }^{100}$ Two further MPs had also been identified as technically ineligible to stand as MPs under the Disqualification Act 1878. One of the "Auckland rats," William Colbeck (Marsden), ${ }^{101}$ and also Major Wiremu Te Wheoro (Western Māori), held government contracts or were government employees and therefore were subject to challenges as well.

In order to remedy the technical electoral mess, an Election Validation Act was passed in November 1880 to validate the elections of William Colbeck, Major Te Wheoro and Hōne Mohi Tāwhai, which effectively ended Hirini Taiwhanga's efforts to upend the Northern Māori election. In a letter to Premier John Hall dated 17 November 1879, Taiwhanga pleaded for the government to pay his hefty expenses of nearly $\mathfrak{£ 7 9}$, incurred from his election petition efforts.

Journal of New Zealand Studies NS32 (2021), 40-59 - https://doi.org/10.26686/jnzs.iNS32.6862 
Taiwhanga was clearly in favour of John Hall's administration and he indicated that George Beetham (Wairarapa) had given him assurances that his costs would be met. He also indicated that he had especially become ridiculed by the opposition MPs Tole (Eden), Speight (Auckland East), and Lundon (Mangonui and Bay of Islands) for his fruitless efforts to unseat Hōne Mohi Tāwhai. ${ }^{102}$

\section{Discussion}

By the end of 1879, election petitions being determined by the House of Representatives had become very unsatisfactory. Essentially, select committees that determined election outcomes became stacked with factions who held predetermined views. The debates within Parliament as to whether to appoint a committee in the first place as well as committee hearings produced heightened animosity between the members, and especially so when the numbers between the government and opposition were extremely tight. Accordingly, the Election Petitions Act 1880 removed decisions about challenges to elections from the MPs, transferring this power to two judges of the Supreme Court. Māori would therefore have to battle each other in the very expensive domains of the Courts. And they were certainly up to doing so, as the years went on. For example, Hirini Taiwhanga, again, challenged Wi Kātene in the 1887 Northern Māori byelection. And he was highly likely to have succeeded in unseating him if it was not for a general election being called the same year, which Hirini Taiwhanga managed to finally win.

Disputing the outcome of elections through petitions to the House of Representatives was really no different to what Māori leaders generally were already doing anyway. Māori leaders had been involved in much correspondence by way of protest or petition between themselves and government officials even before these elections. The Appendices to the Journal of the House of Representatives, for instance, contain references to the airing of a myriad of grievances, usually over land, well before the 1870 s election petitions. So election petitions were yet another mechanism for Māori to air their disputes.

This examination of the two election petitions of 1876 and 1879 has shown how democracy and politics worked in practice in the 1870s, in the context of challenges before the House of Representatives. This was not only for Māori, but also in the Pākehā political arena as well. In the case of the Eastern Māori election of 1876, it was illuminating how returning officers actually collected votes from Māori before election day. They just recorded those votes for the relevant candidate. And with the recording of votes, it is a mistake to generalise that all iwi or hapū more or less vote in a bloc fashion. Relationships between tribal areas and within tribal groups operated at times in different political and social settings. Not all sections of a particular tribal group voted the same way. Karaitiana Takamoana managed to pick up voters in Te Arawa and Ngāti Porou outside of his own iwi affiliations. Hirini Taiwhanga, in his 1879 challenge ,showed how individual Māori were tenacious enough to keep running for election, and mounting challenges even after they lost. Taiwhanga's doggedness and determination did pay off eventually in his general election win for Northern Māori in 1887. Unfortunately, he only served for three years as he died on the night he got re-elected in the 1890 election.

The great Māori political characters involved in the electoral challenges also provide a window into the complex tribal and kin-group dynamics of the time as well. The Ngāti Porou leaders Rāpata Wahawaha, Hēnare Potae, and Hōtene Porourangi going against the Ngāti Kahunungu leaders Karaitiana Takamoana and Hēnare Tomoana was just a continuation of older political rivalries that outsiders to those kin groups could not truly understand. ${ }^{103}$ Wiremu Wanoa was kin to Rāpata Wahawaha, Hēnare Potae, and Hōtene Porourangi, yet he backed Karaitiana and

Journal of New Zealand Studies NS32 (2021), 40-59 - https://doi.org/10.26686/jnzs.iNS32.6862 
Hēnare. Mōkena Kōhere, of Ngāti Porou, who served in the Legislative Council, was drawn into the 1876 challenge by having to give evidence in the dispute, which put kinship pressures upon him as well. In the twenty-first century, we will never know the depths of complexities within these kin-group dynamics, but the historical record alludes to their existence nonetheless. Māori continued to navigate these complicated relationships within their own communities, and at times they collided with or were on display in parliamentary procedures such as election petitions.

The complexities of the relationships within Northern Māori political characters challenges even the most seasoned researcher today. Hōne Mohi Tāwhai, Hirini Taiwhanga, Timoti Puhipi, Heta Te Hara and Hōri Karaka Tāwhiti were significant Northern Māori political leaders all linked with the Ngā Puhi Confederation of tribes and other northern iwi and their ever-shifting power clusters. The 1879 challenge by Hirini Taiwhanga needs to be seen in the context of varfious Northern Māori leaders trying to exert dominance one way or another. In both the 1879 and 1876 Northern Māori elections, the votes were split more or less equally between five candidates, demonstrating the fierce loyalties and competition between kin groups within Northern Māori at the time.

Table 2. Results of the Northern Māori Election in 1876 and 1879

\begin{tabular}{|l|l|}
\hline $\begin{array}{l}\text { Election } \\
\text { Year }\end{array}$ & Candidates with results \\
\hline $1876^{104}$ & $\begin{array}{l}\text { Hōri Karaka Tāwhiti (335); Timoti Puhipi (277); Rei Tetai (252); Wi } \\
\text { Kātene (226); Mitai Pene Taui (218); Hirini Taiwhanga (17) }\end{array}$ \\
\hline $1879^{105}$ & $\begin{array}{l}\text { Hōne Mohi Tāwhai (397); Hirini Taiwhanga (332); Timoti Puhipi (303); } \\
\text { Heta Te Hara (233); Hōri Karaka Tāwhiti (204) }\end{array}$ \\
\hline
\end{tabular}

The dynamics of the individual Māori politicians surrounding the election petitions was, however, just one constituent part of the electoral challenges. The other important aspect related to the wider political machinations being played out between Pākehā politicians as well. The Māori MPs were caught between the warring political factions and shifting alliances within the Fox, Vogel, McLean, and Hall political blocs and the Stafford and Greyite factions within Parliament. There were larger-than-life political characters such as Donald McLean and Sir George Grey and their cameleon-like approaches to Māori issues. McLean sought an opportunity to rerun the Eastern Māori election in 1876 to unseat a political foe, Karaitiana Takamoana, and potentially seat his friend Hōtene Porourangi as the Eastern Māori MP. Sir George Grey needed to stop Hirini Taiwhanga's electoral petition in order to shore up his support and regain the government benches with Hōne Mohi Tāwhai staying exactly where he was in the Northern Māori seat for 1879. There were the legal and political brawlers such as John Sheehan and Joseph Tole who as "street" lawyers were going to fight for their causes to ensure Karaitiana Takamoana and Hōne Mohi Tāwhai were going to keep their Eastern Māori and Northern Māori seats in the 1876 and 1879 elections. And there was the cunning of John Hall, who could not be underestimated. He successfully managed to sway four Auckland MPs along with the Māori MP Hēnare Tomoana to bring down the Grey Government. And yet, when it came to challenging Hōne Mohi Tāwhai, he called for a thorough investigation of the issue, and passed the Election Validation Act 1880 because one of his own supporters, William Colbeck could be disqualified. 
And this is the great lesson of election petitions. They involve raw politics, with all the political theatre and power play which have as much significance in today's politics as they have done in the past. The seating of Winston Peters as an MP in Parliament and the ousting of Malcolm Douglas in 1979 as a result of the Hunua election petition was very dramatic indeed. Trying to unseat Hēnare Kaihau from the Western Māori seat in 1908 was at best opportunistic but nonetheless it cost a significant amount of money for the challenger Pēpene Eketone. And a thorough investigation of those two challenges by future scholars would reveal political complexities indeed. In the 1870 s, when New Zealand governments were particularly unstable, the roles that Māori MPs played were significant because no government knew exactly the numbers they could rely on in the House. But the settling of the Māori election petitions in 1876 and 1879 not only give a window into the complexities of Māori politics at the time, they also gave a window into the stormy Pākehā politics of the 1870s.

\footnotetext{
${ }^{1}$ The exact venue (which particular building) of the designated polling booth is unknown. In the Gazette it refers to the Rūnanga house at Waitetuna. And in the Court case, it refers to the meeting house. See Gazette, 31 October 1908, 2827. All newspaper entries for this article are from the Papers Past website, https://paperspast.natlib.govt.nz, unless otherwise stated. See also In re The Western Maori Election Petition, 28 New Zealand Law Reports (NZLR) 843 (1909).

${ }^{2}$ See John Wilson, "The Origins of the Māori Seats," Parliamentary Library research paper, (Wellington: Parliamentary Library, 2003), 13. Secret Ballot voting was available in the European seats from 1870.

${ }^{3}$ In re The Western Maori Election Petition, 28 NZLR 843, 845 (1909).

${ }^{4}$ In re The Western Maori Election Petition, 28 NZLR 843, 845 (1909).

${ }^{5}$ Ropata Te Ao was the Western Māori MP from 1893 to 1896, when he was defeated by Kaihau. See New Zealand Times, 29 December 1893, 3. Ropata Te Ao was also the subject of an electoral complaint by Pēpene Eketone in the 1893 election as well.

${ }^{6}$ Taranaki Herald, 3 April 1897, 2.

${ }^{7}$ Ian Wishart, Winston: The Story of a Political Phenomenon (Auckland: Howling at the Moon, 2014).

${ }^{8}$ Re Hunua Election Petition, 1 NZLR 251 (1979).

${ }^{9}$ Barry Gustafson, His Way: A Biography of Robert Muldoon (Auckland: Auckland University Press, 2000).

${ }^{10}$ New Zealand Constitution Act 1852 (UK), section 45.

${ }^{11}$ New Zealand Constitution Act 1852 (UK), sections 32, 33, 40-44.

12 The following works are extremely illuminating in giving a broad view of the adoption of New Zealand's government and democratic institutions. Leslie Lipson, The Politics of Equality: New Zealand's Adventure in Democracy (Chicago: University of Chicago Press 1948); B. Ritchie and H. G. Hoffman, "The Electoral Law of New Zealand: A Brief History," Report of the Royal Commission on the Electoral System: Towards a Better Democracy, The Royal Commission on the Electoral System 1986 (Wellington: Government Printers, 1986), Appendix A; M. P. K. Sorrenson, "A History of Māori Representation in Parliament," Report of the Royal Commission on the Electoral System: Towards a Better Democracy, The Royal Commission on the Electoral System 1986 (Wellington: Government Printer, 1986), Appendix B; Neill Atkinson, Adventures in Democracy: A History of the Vote in New Zealand (Dunedin: University of Otago Press, 2003).

${ }^{13}$ Māori Representation Act 1867, section 5.

${ }^{14}$ Māori Representation Act 1867, sections 2 and 6. The vote extended to all Māori males over the age of 21 who were not convicted of treason, felony or any other infamous offence. See Sorrenson, "A History of Māori Representation in Parliament."
} 
${ }^{15}$ Keith Sinclair, "The Maori in Politics, 1840-67," in The Maori and New Zealand Politics, ed. J. G. A. Pocock (Auckland: Blackwood and Janet Paul, 1965), 14-15; Atkinson, Adventures in Democracy, 26; Paul Moon, "“A Proud Thing To Have Recorded': The Origins and Commencement of National Indigenous Political Representation in New Zealand through the 1867 Maori Representation Act," The Journal of New Zealand Studies 16 (2013): 52-65.

${ }^{16}$ Wanganui Chronicle, 19 May 1887, 2.

${ }^{17}$ Wi Pere and James Carroll were involved in claims and counterclaims against each other over the Eastern Māori seat. Wi Pere was ousted from the seat in 1887, and he took an election petition (although unsuccessful) against James Carroll as a result. New Zealand Herald, 25 November 1887, 5. ${ }^{18}$ Election Petitions Act 1880, section 7.

${ }^{19}$ Ranginui Walker, Ka Whawhai Tonu Matou: Struggle without End (Auckland: Penguin, 1990), 98 185; Vincent O'Malley, The Great War for New Zealand: Waikato 1800-2000 (Wellington: Bridget Williams Book, 2016); Michael Belgrave, Dancing with the King: The Rise and Fall of the King Country 1864-1885 (Auckland: Auckland University Press, 2017); Ron Crosby, Küpapa: The Bitter Legacy of Mãori Alliances with the Crown (Auckland: Penguin, 2015).

${ }^{20}$ John Cookson, "How British? Local Government in New Zealand to c. 1930," New Zealand Journal of History 41, no. 2 (2007):143-60; W. P. Morrell, The Provincial System in New Zealand, 1852-1876 (London: Longmans, 1932).

${ }^{21}$ Raymond Miller, Party Politics in New Zealand (Oxford, Oxford University Press 2005), 25-41.

${ }^{22}$ Although Keith Sinclair's work had its main focus on the late 1880s, he nonetheless had a commentary on New Zealand politics in the 1870s and 1880s, which is still very instructive. See Keith Sinclair, "The Significance of the Scarecrow Ministry 1887-1891," in Studies of a Small Democracy: Essays in Honour of Willis Airy, ed. Robert Chapman and Keith Sinclair (Auckland: Blackwood and Janet Paul, 1963), 102-26; See also Raewyn Dalziel, "The Politics of Settlement," The Oxford History of New Zealand, ed. Geoffrey W. Rice (Auckland: Oxford University Press, 1992), 87-111.

${ }^{23}$ Frederick Nene Russell (Northern Māori) and Mete Kīngi Paetahi (Western Māori).

${ }^{24}$ Tāreha Te Moananui (Eastern Māori).

${ }^{25}$ Lyttelton Times, 3 July 1868, 3.

${ }^{26}$ James Cowan, Sir Donald McLean (Dunedin: A. H. and A. W. Reed, 1940); Ray Fargher, The Best Man Who Ever Served the Crown? The Life of Donald McLean (Wellington: Victoria University Press, 2007); Keith Sinclair and Raewyn Dalziel, "Fox, William," Dictionary of New Zealand Biography, first published in 1990, Te Ara-the Encyclopedia of New Zealand, https://teara.govt.nz/en/biographies/1f15/fox-william (accessed 28 July 2020); Raewyn Dalziel, Julius Vogel (Auckland: Auckland University Press, 1986).

${ }^{27}$ Wanganui Herald, 2 February 1871, 2.

${ }^{28}$ The results were Wi Parata (258); Major Kemp (186); Mete Kingi Paetahi (155). Otago Witness, 25 February 1871, 5 .

${ }^{29}$ The results were Hori Kerei Taiaroa (144); Wi Kātene Tuoho (70); Thomas Green (60). Star, 24 February 1871,3 .

${ }^{30}$ Press, 5 January 1876, 2.

${ }^{31}$ West Coast Times, 3 March 1881, 2.

${ }^{32}$ Wanganui Herald, 28 November 1881, 2.

${ }^{33}$ The results were Hōri Kerei Taiaroa (231); Tare Wetere Te Kahu (134). Waikato Times, 29 July 1884, 2.

${ }^{34}$ Reports of the Native Affairs Committee. Nga Kupu a Te Komiti o Te Runanga mo nga mea Māori, Appendix to the Journals of the House of Representatives (AJHR), I-02, 10 (1885).

${ }^{35}$ The four candidates vying for the seat were Wi Kātene, Hirini Taiwhanga, Hoane Pate, and a fourth candidate whose name is unknown in the historical record to date. Daily Southern Cross, 6 February 1871,5 . 
${ }^{36}$ Keith Sinclair, Kinds of Peace; Maori People after the Wars, 1870-85 (Auckland: University Press, 1991), 89.

${ }^{37}$ Edmund Bohan, Edward Stafford: New Zealand's First Statesman (Christchurch: Hazard Press, 1994), 348-65; Judith Bassett, Sir Harry Atkinson 1831-1892 (Auckland: Auckland University Press, 1975), 33-44.

${ }^{38}$ Sharon Mary Cole, "The Repudiation Movement: A Study of the Maori Land Protest Movement in Hawkes Bay in the 1870s" (master's thesis, Massey University, 1977).

${ }^{39}$ Waka Māori, 14 December 1875, 304-06.

40 "Samuel Locke (1836-1890)," Dictionary of New Zealand Biography, vol. I , ed. G. H. Scholefield, (Wellington: Department of Internal Affairs, 1940), 501.

${ }^{41}$ Henare Matua was also part of the repudiation movement and worked against Donald McLean. See Angela Ballara, "Matua, Henare," Dictionary of New Zealand Biography, first published in 1990, Te Ara-the Encyclopedia of New Zealand, https://teara.govt.nz/en/biographies/1m27/matua-henare (accessed 29 July 2020).

${ }^{42}$ Mita Hikairo is also known as Wi Hikairo as well as other variations of his name such as Wiremu Hikairo. See a reference to this in Jenifer Curnow, "Hikairo, Wiremu," Dictionary of New Zealand Biography, first published in 1990, Te Ara-the Encyclopedia of New Zealand, https://teara.govt.nz/en/biographies/1h19/hikairo-wiremu (accessed 29 July 2020).

${ }^{43}$ Wananga, 8 January 1876, 465.

${ }^{44}$ Bay of Plenty Times, 19 January 1876, 3; New Zealand Herald, 14 January 1876, 3.

${ }^{45}$ See Steven Oliver, "Te Rangi-puawhe, Te Keepa," Dictionary of New Zealand Biography, first published in 1990, Te Ara-the Encyclopedia of New Zealand,

https://teara.govt.nz/en/biographies/1t68/te-rangi-puawhe-te-keepa (accessed 29 July 2020).

${ }^{46}$ Curnow, "Hikairo, Wiremu."

${ }^{47}$ Crosby, Küpapa, 249.

${ }^{48}$ Monty Soutar, "Ngāti Porou Leadership — Rāpata Wahawaha and the Politics of Conflict. Kei te Ora Nei Hoki Tātou, me To Tātou Whenua" (PhD thesis, Massey University, 2000); Steven Oliver, "Wahawaha, Rāpata," Dictionary of New Zealand Biography, first published in 1990, updated September, 2013, Te Ara-the Encyclopedia of New Zealand, https://teara.govt.nz/en/biographies/1w1/wahawaha-rapata (accessed 29 July 2020).

${ }^{49}$ Soutar, "Ngāti Porou Leadership," 269.

${ }^{50}$ Eastern Māori Electoral District. Papers relative to an election of a member to serve in the House of Representatives, AJHR, I-3A, 2 (1876).

${ }^{51}$ Henry Halse was simultaneously a judge of the Native Land Court and the undersecretary of Native Affairs. "Henry Halse (1820-1888)," Dictionary of New Zealand Biography, Vol. I, ed. G. H.

Scholefield, (Wellington: Department of Internal Affairs, 1940), 348.

${ }^{52}$ AJHR, I-3A, 2 (1876).

${ }^{53}$ AJHR, I-3A, 3 (1876).

${ }^{54}$ Reports of the Eastern Maori Election Committee with minutes of the evidence, AJHR, I-03,10 (1876). Presumably the lawyers were James Wren Carlile of Napier, Frederick Whitaker in Auckland and George Cook in Dunedin. Both Whitaker and Cook were leading men in the profession in Auckland and Dunedin respectively. The correspondence that was recorded by the committee merely refer to Mr Carlisle, solicitor, and Messrs Cook and Whitaker, barristers (Carlile is spelt wrong in the record).

55 These were 37 votes for Keepa and 11 votes for Karaitiana at Taupo. Letter from Samuel Locke to Donald McLean, 20 January 1876, Inward Letters Samuel Locke, MS-Papers-0032-0394, MS-Group1551: McLean, Donald (Sir) 1820-1877: Papers, Alexander Turnbull Library, Wellington (ATL).

${ }^{56}$ Letter from Samuel Locke to Donald McLean, 20 January 1876, Inward Letters Samuel Locke, MSPapers-0032-0394, MS-Group-1551: McLean, Donald (Sir) 1820-1877: Papers, ATL.

${ }^{57}$ AJHR, I-3A, 3 (1876).

${ }^{58}$ AJHR, I-3A, 3 (1876). 
${ }^{59}$ AJHR, I-03 (1876).

${ }^{60}$ AJHR, I-03, 1 (1876).

${ }^{61}$ AJHR, I-03, 1 (1876).

${ }^{62}$ This is loosely based upon the division in the House noted in the newspapers, and deducing that Stafford would have voted against McLean because he was in opposition. This is making an assumption that it was passed with a 6-4 majority, and therefore Bastings, Lumsden and Reid, though recorded as doubtful or absent, would have formed a majority bloc with McLean, Hunter and Williams. See Thames Advertiser, 20 June 1876, 3.

${ }^{63}$ AJHR, I-03, 1 (1876).

${ }^{64}$ Globe, 5 July 1876, 2.

${ }^{65}$ Rarawa Kohere, "Kōhere, Mōkena," Dictionary of New Zealand Biography, first published in 1990, Te Ara-the Encyclopedia of New Zealand, https://teara.govt.nz/en/biographies/1k15/kohere-mokena (accessed 10 September 2020).

${ }^{66}$ AJHR, I-03, 5-6, 8-9,18-20 (1876).

${ }^{67}$ AJHR, I-03, 12, 20 (1876).

${ }^{68}$ AJHR, I-03, 11 (1876).

${ }^{69}$ AJHR, I-03, 8 (1876).

${ }^{70}$ AJHR, I-03, 21 (1876).

${ }^{71}$ AJHR, I-03, 21-22 (1876).

${ }^{72}$ AJHR, I-03, 21-22 (1876).

${ }^{73}$ AJHR, I-03, 11 (1876).

${ }^{74}$ AJHR, I-03, 21 (1876).

${ }^{75}$ AJHR, I-03 (1876).

${ }^{76}$ Letter from E. Fox to Vogel, 13 September 1879, Letters from Fox re political and general news about New Zealand, MS-Papers-2072-31, Vogel, Julius (Sir) 1835-1899: Papers 1852-1899, 1943 [Collection], ATL.

${ }^{77}$ Gary Scott, "Te Wheoro, Wiremu Te Morehu Maipapa," Dictionary of New Zealand Biography, first published in 1990, updated June, 2017, Te Ara-the Encyclopedia of New Zealand, https://teara.govt.nz/en/biographies/1t87/te-wheoro-wiremu-te-morehu-maipapa (accessed 19 August 2020).

${ }^{78}$ Letter from C. J. Stevens to Stafford, 4 October 1879, Inward correspondence-E. C. J. Stevens, 1871-1882, MS-Papers-0028-45, Stafford, Edward William, 1819-1901: Papers, ATL.

${ }^{79}$ New Zealand Parliamentary Debates (NZPD), vol. 32 (1879): 162-63. Henare Tomoana (Eastern Māori) voted against the confidence in Grey’s government. The other three Māori MPs, Wiremu Te Wheoro (Western Māori), Ihaia Tainui (Southern Māori) and Hōne Mohi Tāwhai (Northern Māori), voted for Grey.

${ }^{80}$ Bassett, Sir Harry Atkinson, 76.

${ }^{81}$ Letter from E. Fox to Vogel, 31 October 1879, Letters from Fox re political and general news about New Zealand, MS-Papers-2072-31, Vogel, Julius (Sir) 1835-1899: Papers 1852-1899, 1943

[Collection], ATL.

82 John Ormond's recollection of the meeting between Hēnare Tomoana and Te Wheoro with John Hall dated 6 October 1879, MSY-1098: Miscellaneous political letters and telegrams received by Hall previous to and during his Premiership [WGa Vol 37], 1879, Hall, John (Sir), 1824-1907: Papers (MS-Group-0033), ATL.

${ }^{83}$ Tomoana's statement, MSY-1098: Miscellaneous political letters and telegrams received by Hall previous to and during his Premiership [WGa Vol 37], 1879, Hall, John (Sir), 1824-1907: Papers (MS-Group-0033), ATL.

${ }^{84}$ Minutes of meetings of John Hall and others dated 7 October 1879, MSY-1098: Miscellaneous political letters and telegrams received by Hall previous to and during his Premiership [WGa Vol 37], 1879, Hall, John (Sir), 1824-1907: Papers (MS-Group-0033), ATL.

${ }^{85}$ Auckland Star, 11 September 1879, 3. 
${ }^{86}$ Lyttleton Times, 16 September 1879, 6.

${ }^{87}$ NZPD, vol. 32 (1879): 303-04.

${ }^{88}$ This is based upon information from the Lyttleton Times, 17 September 1879, 5.

${ }^{89}$ Auckland Star, 16 December 1930, 9.

${ }^{90}$ NZPD, vol. 32 (1879): 302.

${ }^{91} N Z P D$, vol. 32 (1879): 302-03.

${ }^{92}$ NZPD, vol. 32 (1879): 304.

${ }^{93}$ NZPD, vol. 32 (1879): 309-10.

${ }^{94}$ NZPD, vol. 32 (1879): 311.

${ }^{95} \mathrm{NZPD}$, vol. 32 (1879): 309.

${ }^{96}$ Auckland Star, 24 April 1903, 5.

${ }^{97}$ AJHR, I-03, 21-22 (1876).

${ }^{98}$ NZPD, vol. 32 (1879): 309.

${ }^{99}$ NZPD, vol. 32 (1879): 305, 307-08, 310-11, 314.

${ }^{100}$ City of Christchurch Election (Report of Select Committee on), together with Minutes of Proceedings and Appendix, AJHR, I-10 (1879).

${ }^{101}$ Ebenezer Fox wrote to Vogel and mentioned that Colbeck would come to grief as he had a contract for a steam mail service on the Auckland Coast. Letter from E. Fox to Vogel, 31 October 1879, Letters from Fox re political and general news about New Zealand, MS-Papers-2072-31, Vogel, Julius (Sir) 1835-1899: Papers 1852-1899, 1943 [Collection], ATL.

${ }^{102}$ Letter of S. D. Taiwhanga to Premier John Hall dated 17 October 1879, MSY-1098: Miscellaneous political letters and telegrams received by Hall previous to and during his Premiership [WGa Vol 37], 1879, Hall, John (Sir), 1824-1907: Papers (MS-Group-0033), ATL.

${ }^{103}$ Nepia Mahuika navigates various issues surrounding the understanding of Māori history on the Māori people's own terms. That way, the complexities regarding relationships amongst Māori take on different understandings of various social contexts involving individuals. Nepia Mahuika, "New Zealand History is Māori History: Tikanga as the Ethical Foundation of Historical Scholarship," New Zealand Journal of History 49, no.1 (2015): 5-30.

${ }^{104}$ Auckland Star, 20 January 1876, 3.

${ }^{105}$ Auckland Star, 11 September 1879, 3. 